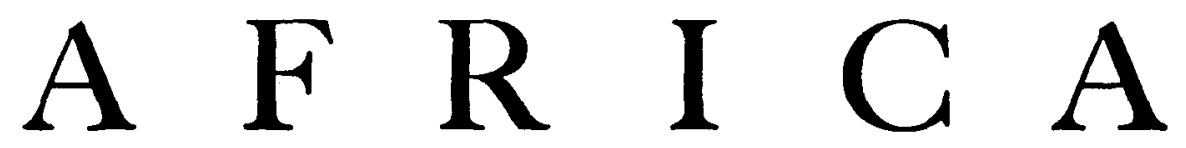

JOURNAL OF THE INTERNATIONAL AFRICAN INSTITUTE

\title{
OBITUARY
}

\section{SIEGFRIED FREDERICK STEPHEN NADEL}

WVE have to record with deep regret the death of a distinguished former Research Fellow of the Institute, Professor S. F. Nadel.

Following his earlier studies in psychology and anthropology in the Universities of Vienna and Berlin, Dr. Nadel came to England in 1932 with a Rockefeller Fellowship to study anthropology under Professor Malinowski. Two years later he was awarded a Field Research Fellowship of the Institute which he devoted to a study of the Nupe of Nigeria. Within a short time after his return from the field, he completed a monograph on the economic life of the Nupe and the political organization of the Emirate of Bida which was published under the title $A$ Black Byzantium in 1942. Meanwhile Dr. Nadel had, with characteristic versatility, immersed himself in the life of a very different people and carried out for the Government of the A.E. Sudan a study of the social organization and the effects of external influences on the small tribes of the Nuba Mountains. This study formed the subject of his book The Nuba (1947) and of a number of papers. During the war he was engaged in intelligence and advisory duties with the British forces in the Sudan and later served in the British Military Administration in Etitrea and Tripolitania, where his anthropological knowledge and his flair for the rapid assimilation and appraisal of new material proved most valuable. At this time he wrote a short monograph Land Tenure on the Eritrean Plateau (1944) and prepared the first ethnographic maps of Eritrea and Ethiopia. He returned to his Nupe studies after the war, when he held posts in the Universities of London and Durham, and published several papers on Nupe cults and, more recently, a monograph on Nupe Religion (1954). He also became deeply interested in problems of theory and method in social anthropology, to which he made a notable contribution in his Foundations of Social Anthropology (195 I), in particular by making anthropologists more fully aware of problems and theoretical developments in other disciplines that were relevant to their own studies. In a number of recent papers on aspects of belief and cultural values among African peoples, he developed a most fruitful application of comparative methods in social anthropology.

In r950 Dr. Nadel was appointed Professor and Head of the Department of Anthropology in the National University of Australia at Canberra, where he built

'Africa', the Journal of the International African Institute, is published by the Institute, but except where otherwise stated the writers of the articles are responsible for the opinions expressed. 
up a research school which was exceptionally active in New Guinea. But he continued his personal interest in the African field, as is evident in the penetrating review article on recent developments in the study of primitive law which appears elsewhere in this number of Africa.

Professor Nadel was equally stimulating in his writings, as a lecturer, and in debate. He presented his concepts and developed his argument with exceptional clarity; he could marshal a wide range of data with skill and yet maintain a forceful, conversational style. The loss to anthropology and to African studies by his death at the height of his powers is a grievous one, and the sincere sympathy of this Institute will be extended to his family and his colleagues. They may be encouraged by the assurance that his contribution will continue to stimulate the advancement of knowledge in these fields.

DARYLL Forde

AFTER this issue of the Journal had gone to press we received the distressing news of the death of Professor Marcel Griaule, Consultative Director and member of the Executive Council of the Institute. An appreciation of this distinguished scholar and notable Africanist will be published in the next issue of Africa.

\section{CONTRIBUTORS TO THIS NUMBER}

Mme Germaine Dieterlen, Maître des Conférences à l'École pratique des Hautes Études, Paris; membre des Missions Griaule au Soudan français; auteur de Les Ames des Dogons, Essai sur la Religion bambara, etc.

M. G. Marwick, Senior Lecturer in Sociology at the University of Natal, Durban; formerly Head of the Department of Psychology at Fort Hate University College; author of 'The social context of Cewa witch beliefs', Africa, 1952, and other papers.

Professor S. F. NADEL, lately Head of the Department of Anthropology and Sociology in the National University of Australia, Canberra. Former Research Fellow of the International African Institute; author of A Black Byzantium, The Nuba, Nupe Religion; contributor to African Systems of Kinship and Marriage and African Political Systems.

Dr. Phillip V. Tosias, Senior Lecturer in Anatomy, University of the Witwatersrand, Johannesburg; author of Chromosomes, Sex-cells and Evolution in a Mammal (1956), and numerous papers on South African prehistory and archaeology. 